\title{
Screening and identification of host cellular factors interaction with immediate-early protein ICP22 of herpes simplex virus type 1
}

\author{
Junji Xing ${ }^{*}$, Fusen Lin, Meili Li, Shuai Wang, Hong Guo, Chunfu Zheng \\ From Institut Pasteur International Network Annual Scientific Meeting \\ Hong Kong. 22-23 November 2010
}

Herpes simplex virus type 1 (HSV-1) is a common and widely studied human pathogen that can replicate in epithelial cells and other cells of the host or alternatively can remain latent in peripheral neurons. ICP22 consists of 420 residues and is encoded by a spliced mRNA transcribed from the US1 gene. It is necessary for efficient HSV-1 growth in animal models of infection as well as for efficient in vitro growth in some, but not all, cultured cells. For example, ICP22 mutants grow well in African green monkey kidney (Vero) cells, but not in human embryonic lung (HEL) cells. ICP22 is extensively phosphorylated during infection, primarily by UL13 and another viral protein kinase, US3. In addition to inducing the modification of the host cell RNA Pol II, several other functions have been attributed to ICP22; these functions include the induction of certain viral $\mathrm{L}$ genes, the alteration of cell cycle-related proteins, and the determination of virion composition. It is clear that ICP22 is a multifunctional protein localized to the nucleus of infected cells, however, the host cellular factors of ICP22 as well as the biological functions of their interactions are still little known. In the present study, an yeast two-hybrid system was applied to identify the host cellular factors of ICP22 and five target candidates were yielded: (1) TATA box binding protein -associated factor (TAF1); (2) TAO kinase 3 (TAOK3); (3) Alpha thalassemia/mental retardation syndrome X-linked (ATRX); (4) Cyclin-dependent kinase 9 (CDK9); (5) Ras association domain family member 9 (RASSF9); (6) occludin/ELL domain containing 1 (OCEL1). To confirm some of the interactions by co-localization in living cells, ICP22 and two candidate targets were tagged with

State Key Laboratory of Virology, Wuhan Institute of Virology, Chinese Academy of Sciences, Wuhan 430071, PR China enhanced cyan fluorescent protein (ECFP), enhanced yellow fluorescent protein (EYFP), respectively. Upon cotransfection of COS-7 cells, RASSF9-EYFP and OCEL1-EYFP both co-localized with ICP22-ECFP in distinct nuclear domains, indicating they are host cellular factors interaction with viral ICP22 under physiological conditions.

Published: 10 January 2011

doi:10.1186/1753-6561-5-S1-P104

Cite this article as: Xing et al:: Screening and identification of host cellular factors interaction with immediate-early protein ICP22 of herpes simplex virus type 1. BMC Proceedings 2011 5(Suppl 1):P104.

Submit your next manuscript to BioMed Central and take full advantage of:

- Convenient online submission

- Thorough peer review

- No space constraints or color figure charges

- Immediate publication on acceptance

- Inclusion in PubMed, CAS, Scopus and Google Scholar

- Research which is freely available for redistribution 